\title{
Pamali: Intervensi dan Pengaruhnya terhadap Pembentukan Pola Pikir Logis Remaja dalam Masyarakat Banjar
}

\author{
Sriwati $^{1}$, Wawan Prasetyo ${ }^{2}$, Muhammad Iqbal ${ }^{3}$ \\ ${ }^{1}$ Universitas Lambung Mangkurat, Banjarmasin \\ ${ }^{2}$ Universitas Pendidikan Indonesia, Bandung \\ ${ }^{3}$ Universitas Islam Negeri Maulana Malik Ibrahim, Malang
}

\begin{tabular}{l}
\hline Article Info \\
\hline Article history: \\
Accepted: 06 Januari 2022 \\
Publish: 11 Januari 2022 \\
\\
\hline Keywords: \\
Pamali \\
Adolescents \\
Logical Thinking Patterns \\
Banjar Society
\end{tabular}

Info Artikel

Article history:

Diterima: 06 Januari 2022

Terbit: 11 Januari 2022

\begin{abstract}
Pamali is one of the rules in society that is socialized and taught by parents to children in the form of prohibitions accompanied by threats with the intention of making it a control over children's behavior. Every parent's advice certainly has a good intention, but often the prohibitions that are collected in the pamali category are difficult to understand and even there is no relevance between cause and effect if violated. However, this tradition is able to intervene and influence the logical thinking ability of adolescents in Banjar society. The type of research used is descriptive qualitative. The research subjects included some students of SMA Global Islamic Boarding School. The technique used in retrieval of information is purposive sampling, namely by taking research subjects who meet the following criteria: 1) students who are familiar with the term pamali, 2) students born in the Banjar community, 3) students who are included in the category of having a high and low logical mindset. The results showed that the pamali tradition as folklore has a vital role in influencing the logical thinking patterns of adolescents. This is shown by their fear which is more dominant than their belief in the pamali tradition. Teenagers who believe in the pamali tradition tend to have an excessive fear of the consequences that do contain a lot of bad luck in it. Adolescents who have low logical thinking skills tend to believe in the pamali tradition. Then when compared to teenagers who have good logical thinking skills, they tend to be better able to filter the impact of the pamali tradition.

\begin{tabular}{l}
\hline ABSTRACT \\
\hline Pamali merupakan salah satu tata aturan dalam masyarakat yang disosialisasikan dan diajarkan \\
oleh para orangtua kepada anak berupa larangan yang disertai ancaman dengan maksud \\
menjadikannya sebagai kontrol terhadap perilaku anak. Setiap nasihat orangtua tentu \\
mempunyai maksud yang dianggap baik, tetapi seringkali larangan-larangan yang terhimpun \\
dalam kategori pamali sulit dipahami bahkan tidak ada relevansi antara sebab dengan akibat \\
yang menjadi dampak jika melanggar. Namun, tradisi ini mampu mengintervensi dan \\
mempengaruhi kemampuan berpikir logis remaja dalam masyarakat Banjar. Jenis penelitian \\
yang digunakan adalah deskriptif kualitatif. Subjek penelitian meliputi sebagian siswa/i SMA \\
Global Islamic Boarding School. Adapun teknik yang digunakan dalam pengambilan informasi \\
adalah purposive sampling yaitu dengan mengambil subjek penelitian yang memenuhi kriteria \\
sebagai berikut: 1) siswa/i yang familiar dengan istilah pamali, 2) siswa/i yang terlahir dalam \\
lingkungan masyarakat Banjar, 3) siswa/i yang termasuk kategori memiliki pola pikir logis \\
tinggi dan rendah. Hasil penelitian menunjukkan bahwa tradisi pamali sebagai folklore \\
memiliki peranan yang vital dalam hal mempengaruhi pola pikir logis remaja. Hal ini \\
ditunjukkan oleh rasa takut mereka yang lebih dominan daripada kepercayaan mereka terhadap \\
tradisi pamali. Remaja yang percaya terhadap tradisi pamali cenderung akan memiliki rasa \\
takut yang berlebih terhadap akibat yang memang mengandung banyak kesialan didalamnya. \\
Remaja yang memiliki kemampuan berpikir logis yang rendah cenderung akan percaya dengan \\
tradisi pamali. Kemudian jika dibandingkan dengan remaja yang memiliki kemampuan \\
berpikir logis yang baik cenderung akan lebih mampu menyaring dampak dari tradisi pamali \\
tersebut.
\end{tabular}
\end{abstract}

This is an open access article under the Lisensi Creative Commons Atribusi-BerbagiSerupa 4.0 Internasional

\section{Corresponding Author:}

Sriwati

Universitas Lambung Mangkurat, Banjarmasin

Email: sriwati@ulm.ac.id 


\section{PENDAHULUAN}

Dalam masyarakat Banjar terdapat berbagai ungkapan tradisional (folklore) yang disampaikan secara lisan dan turun temurun dari satu generasi ke generasi lainnya. Ungkapan tersebut biasanya memiliki makna atau maksud tertentu dengan bahasa kias yang mengandung nilai-nilai luhur, moral, etika, nilai-nilai pendidikan yang selalu berpegang teguh pada norma-norma yang berlaku di masyarakat. Sebagaimana diungkapkan oleh Bascom (Danandjaja, 1984: 50), folklore lisan pada umumnya memiliki fungsi sebagai sistem proyeksi, alat pengesahan pranata-pranata dan lembaga sosial kebudayaan, alat pendidikan anak dan masyarakat, alat pemaksa dan pengawas norma masyarakat agar selalu dipatuhi.

Salah satu ungkapan tradisional yang dimaksud disebut dengan pamali. Istilah pamali berasal dari bahasa Sunda, mempunyai makna sama dengan kata pantrang dan cadu (sepadan artinya dengan kata pantang atau tabu), yang artinya pantangan atau larangan tentang suatu tindakan yang dilakukan sehari-hari yang apabila pantangan tersebut dilakukan, maka dianggap dapat mendatangkan kesialan dan biasanya berhubungan dengan masalah kesehatan, keselamatan, jodoh, rezeki, keturunan, dan lain sebagainya (Hutari dalam Jamalie \& Juhriyansyah, 2013: 1055).

Menurut Jamiah et al (2021: 290), orang Banjar mengenal ungkapan pamali ini terutama dari orang tua, kakek ataupun nenek mereka, dan sebagian orang mengetahuinya lewat teman atau tetangga. Hal itu menunjukkan bahwa pamali sebagai tradisi lisan masyarakat Banjar masih ada sampai sekarang. Dalam masyarakat Banjar, pamali berfungsi sebagai kontrol sosial bagi seseorang dalam berkata, bertindak, atau melakukan suatu kegiatan. Selain itu, pamali juga menjadi indikator dalam menilai seseorang, apakah ia patuh dan taat terhadap aturan-aturan yang dibuat oleh masyarakat.

Sebagai tradisi lisan yang tumbuh dan berkembang dalam kehidupan masyarakat Banjar, ungkapan pamali mencerminkan sikap dan pandangan masyarakat tersebut. Setidaknya ada dua hal yang tercermin, pertama masyarakat Banjar adalah masyarakat yang mengutamakan kesopanan dan kesatuan dalam menyampaikan maksud. Larangan tidak disampaikan secara langsung, tetapi dalam bentuk ungkapan lain yaitu kata pamali yang bermakna tabu. Larangan dengan istilah pamali dimaksudkan agar penerima pesan tidak merasa didikte atau digurui. Kedua, penggunaan pamali sebagai media pembentukan karakter terutama yang berkenaan dengan nilai karakter religius, toleransi, disiplin, dan peduli sosial (Harpriyanti \& Komalasari, 2018: 243).

Dengan demikian, pamali bagi masyarakat Banjar menjadi simbol untuk mengisyaratkan baik atau tidaknya sifat dan perilaku seseorang, serta kepatuhannya terhadap norma-norma yang berlaku. Namun, pamali sebagai tolak ukur perilaku masyarakat dan simbol kepatuhan belum secara optimal dipahami dan diimplementasikan oleh masyarakat yang telah melahirkannya. Sehingga makna positif pamali telah mengalami degradasi, bahkan cenderung mengintervensi pola pikir masyarakat Banjar.

Sebagaimana diketahui, pamali adalah bagian dari sastra lisan (folklore) masyarakat Banjar yang secara umum juga berkembang dalam berbagai masyarakat lainnya di seluruh Indonesia, dengan berbagai istilah, maksud, dan tujuan yang kurang lebih sama. Konon, pamali pada zaman dulu digunakan oleh para orangtua untuk mengajarkan disiplin kepada anak-anaknya. Hal ini dilakukan karena keterbatasan pengetahuan para orangtua dalam menjelaskan sesuatu yang kurang tepat untuk dilakukan. Selain itu, kebanyakan anak-anak sering tidak mendengar larangan-larangan yang diberikan, sehingga muncul pemikiran untuk memberikan larangan dengan menyertakan 'ancaman' agar anak-anak dapat mendengar kata-kata mereka.

Seorang remaja bukanlah sosok yang matang untuk dapat menjalani proses perkembangannya seorang diri dalam mencapai tujuan hidup. Masa ini menghadirkan begitu banyak tantangan, karena banyak perubahan yang harus dihadapi mulai dari perubahan fisik, biologis, psikologis, dan sosial (Geldard, 2012:126). Pada tahap inilah proses perubahan penting terjadi, beberapa anak diantaranya mampu menghadapinya dengan baik. Namun, tidak sedikit juga yang 
kesulitan dalam menyesuaikan diri terhadap tantangan tersebut sehingga muncul berbagai konsekuensi baik psikologis, emosional maupun behavioral yang merugikan.

Masa remaja adalah masa perubahan, masa dimana mereka menghadapi berbagai pengalaman baru. Sehingga berhadapan dengan situasi yang tidak terduga dapat menimbulkan kecemasan dan menyebabkan stress. Dalam hal ini, sebagian remaja mempunyai sifat ulet dan memiliki strategi tingkat tinggi dalam mengatasi permasalahan, sementara sebagian yang lain kesulitan dalam berhadapan dengan berbagai tuntutan proses perkembangan yang sedang mereka lakoni. Selain itu, proses adaptasi terhadap berbagai perkembangan diantaranya fisiologi dan psikologi juga turut mempengaruhi kecenderungan perilaku remaja.

Dalam hal ini, fisiologi berkaitan dengan perkembangan jasmani seperti pertumbuhan otot. Sedangkan psikologi mengarah pada perkembangan mental, daya nalar (kognitif), perasaan (afektif), dan aktivitas (motorik). Berpikir adalah proses berkembangnya ide atau konsep pada diri seseorang, dimana proses ini sangat dipengaruhi oleh pengalaman dan informasi yang diperoleh sebelumnya melalui proses pergaulan yang disimpan dalam long term memory (Khodijah, 2006: 118). Oleh karenanya dalam hal ini, lingkungan keluarga sebagai madrasah pertama merupakan faktor penentu utama yang berpotensi dalam membentuk pola pikir anak.

Layaknya sebuah daerah, sebuah keluarga tentu memiliki nilai-nilai religius, tradisi maupun sosial yang ingin diwariskan kepada keturunannya. Adat kebiasaan seperti etika, sopan santun, penghormatan terhadap orang yang lebih tua, cara berinteraksi dengan keluarga dan orang lain, serta pedoman hidup lain yang biasanya dilatarbelakangi oleh agama menjadi pokok dasar pendidikan dalam keluarga. Dimana orangtua mendapat tempat yang tinggi dan terhormat dihadapan anakanaknya.

Seringkali ucapan orangtua yang bersifat nasihat pribadi didasari oleh pengalaman orang tua sendiri, sehingga kebenarannya tak perlu dipertanyakan lagi. Sehingga tidak heran, jika yang terjadi seringkali orangtua menciptakan 'aturan berdasarkan pengalaman' tersebut dengan maksud membentuk perilaku anak-anaknya agar memenuhi cita-cita mereka. Salah satu bentuk aturan yang ditemukan dalam keluarga adalah pamali. Terkait dengan beberapa permasalahan yang telah diungkapkan di atas, maka peneliti tertarik untuk melakukan sebuah penelitian yang berjudul "Pamali: Intervensi dan Pengaruhnya terhadap Pembentukan Pola Pikir Logis Remaja dalam Masyarakat Banjar".

\section{METODE PENELITIAN}

Jenis penelitian yang digunakan adalah deskriptif kualitatif, yaitu penelitian yang menghasilkan data deskriptif yang berupa kata-kata tertulis atau lisan dari orang dan perilaku yang dapat diamati (Bogdan dan Biklen, S. dalam Rahmat, 2009: 2-3). Metode penelitian ini dipilih oleh peneliti untuk mengungkapkan pendapat/tanggapan remaja tentang pamali. Meliputi bagaimana intervensi dan pengaruhnya terhadap pola pikir logis remaja di SMA Global Islamic Boarding School, J1. Trans Kalimatan, Desa Sungai Lumbah, Kecamatan Alalak, Kabupaten Barito Kuala.

Teknik pengambilan informasi yang digunakan adalah purposive sampling yaitu dengan mengambil subjek penelitian yang memenuhi kriteria. Alasan menggunakan teknik ini adalah karena tidak semua sampel memiliki kriteria yang sesuai dengan fenomena yang diteliti (Sugiyono, 2016:85). Adapun kriteria yang menjadi sampel dalam penelitian ini adalah: 1) siswa/i yang familiar dengan istilah pamali, 2) siswa/i yang terlahir dalam lingkungan masyarakat Banjar, 3) siswa/i yang termasuk kategori memiliki pola pikir logis tinggi dan rendah. Pada penelitian ini jumlah informan yang diambil sebanyak 38 orang.

Teknik pengumpulan data yang digunakan dalam penelitian ini, meliputi wawancara, kuesioner/angket, dan dokumentasi. Proses wawancara dilakukan dengan menggunakan pedoman wawancara dalam bentuk pertanyaan open ended question (terbuka). Setiap orang diberikan pertanyaan yang sama untuk mendapatkan keterangan (pandangan, kepercayaan, pengalaman dan 
pengetahuan) secara lisan dari informan tentang pamali. Kuesioner digunakan untuk mengumpulkan informasi tentang ungkapan pamali yang seringkali digunakan dalam masyarakat, serta untuk mengetahui intervensi dan pengaruh pamali terhadap remaja. Dokumentasi/arsip sekolah yang diperoleh dari guru BK digunakan untuk mengetahui kategori siswa yang memiliki logika berpikir dan kemampuan analisa siswa.

Instrumen utama dalam penelitian ini adalah peneliti dan anggota tim peneliti. Jadi, dalam hal ini peneliti bertindak sebagai instrumen sekaligus pengumpul data. Penelitian ini juga menggunakan instrumen lain, yaitu wawancara, kuesioner dan dokumentasi, tetapi fungsinya terbatas sebagai pendukung tugas peneliti sebagai instrumen. Selanjutnya data yang sudah dihimpun dianalisis dengan reduksi data, penyajian data, dan verifikasi.

\section{HASIL TEMUAN DAN PEMBAHASAN}

\subsection{Intervensi Tradisi Pamali terhadap Kehidupan Remaja dalam Masyarakat Banjar}

Dalam masyarakat Banjar terdapat salah satu ungkapan tradisional atau folklore yang disebut dengan pamali, yakni ungkapan-ungkapan yang mengandung semacam larangan atau pantangan untuk dilakukan dan berfungsi sebagai kontrol sosial bagi seseorang dalam berkata, bertindak, atau melakukan suatu kegiatan. Sehingga dapat digunakan sebagai indikator dalam menilai seseorang, apakah ia patuh dan taat terhadap aturan-aturan yang dibuat oleh masyarakat, baik dalam konteks ajaran agama maupun norma-norma sosial (Jamalie \& Juhriyansyah, 2013: 1051).

Selain itu, tradisi pamali juga memiliki fungsi tertentu sebagai refleksi dan cerminan diri dalam melakukan berbagai hal. Sehingga tradisi pamali memiliki pengaruh yang vital dalam pembentukan karakter dan pola pikir khususnya terhadap remaja dalam masyarakat Banjar. Sebagaimana diungkapkan Sugara dan Teguh (Sugara \& Perdana, 2021: 12) bahwa tradisi pamali memiliki berbagai nilai-nilai pendidikan karakter. Nilai-nilai tersebut terdiri atas nilai moral dan sosial.

Berdasarkan hasil angket yang dibagikan secara random kepada siswa/i di SMA Global Islamic Boarding School yang memenuhi kriteria 1) siswa/i yang familiar dengan istilah pamali, 2) siswa/i yang terlahir dalam lingkungan masyarakat Banjar, 3) siswa/i yang termasuk kategori memiliki pola pikir logis tinggi dan rendah. Berdasarkan angket tersebut diperoleh informasi tentang ungkapan pamali yang beredar dikalangan remaja Banjar antara lain sebagai berikut:

Tabel 1. Ungkapan Pamali yang Digunakan dalam Masyarakat Banjar

\begin{tabular}{|c|l|l|}
\hline No & \multicolumn{1}{|c|}{ Pamali } & \multicolumn{1}{c|}{ Akibat } \\
\hline 1. & $\begin{array}{l}\text { Duduk di depan pintu rumah ketika } \\
\text { hujan }\end{array}$ & Bisa disambar petir \\
\hline 2. & Duduk di atas bantal & Bisulan \\
\hline 3. & Memakai payung di dalam ruangan & Memayungi makhluk halus/gaib \\
\hline 4. & Bersiul di malam hari & Memanggil makhluk halus/gaib \\
\hline 5. & Memotong kuku pada malam hari & $\begin{array}{l}\text { Kukunya menjadi kuku makhluk } \\
\text { halus/gaib }\end{array}$ \\
\hline 6. & Nasi nempel di kaki & Kutilan \\
\hline 7. & Bermain di luar rumah ketika senja & Ditangkap Wewe Gombel \\
\hline 8. & Duduk di depan pintu rumah & Sulit mendapatkan jodoh \\
\hline 9. & Tidur dengan cara tiarap & Mendo'akan orangtua cepat meninggal \\
\hline 10. & Kencing di bawah pohon & Alat kelamin menjadi bengkak \\
\hline 11. & Menyapu tidak bersih & Mendapat suami yang brewokan \\
\hline 12. & Merebahkan kepala di atas guling & $\begin{array}{l}\text { Cita-citanya akan terhalang atau sulit } \\
\text { tercapai }\end{array}$ \\
\hline
\end{tabular}




\begin{tabular}{|c|l|l|}
\hline No & \multicolumn{1}{|c|}{ Pamali } & \multicolumn{1}{c|}{ Akibat } \\
\hline 13. & Menyanyi di kamar mandi & Mengundang makhluk halus/gaib \\
\hline 14. & Berfoto bertiga & $\begin{array}{l}\text { Orang yang menempati posisi tengah } \\
\text { akan meninggal duluan }\end{array}$ \\
\hline 15. & Makan berpindah-pindah tempat & Rezeki akan mengalami penurunan \\
\hline 16. & Menyanyi di dapur & Mendapatkan pasangan hidup yang tua \\
\hline 17. & $\begin{array}{l}\text { Tidak menghabiskan makanan di } \\
\text { piring }\end{array}$ & Ayam (peliharaan keluarga) akan mati \\
\hline 18. & $\begin{array}{l}\text { Memangku piring di atas paha saat } \\
\text { makan }\end{array}$ & Istri atau suami nanti dipangku orang lain \\
\hline 19. & Menjahit pakaian pada malam hari & Hidupnya akan susah \\
\hline 20. & $\begin{array}{l}\text { Tidak mencicipi makanan yang } \\
\text { ditawarkan sebelum bepergian }\end{array}$ & Mendapat musibah saat di perjalanan \\
\hline 21. & Keluar masuk rumah lewat jendela & Rumahnya akan kemalingan \\
\hline 22. & $\begin{array}{l}\text { Menggendang benda yang bukan } \\
\text { alat musik gendang }\end{array}$ & Menambah hutang \\
\hline 23. & $\begin{array}{l}\text { Senggoang (dagu bertopang pada } \\
\text { telapak tangan) }\end{array}$ & $\begin{array}{l}\text { Ketika dewasa akan menjadi peminta- } \\
\text { minta }\end{array}$ \\
\hline 24. & Menunjuk pelangi & Jari tangan putus \\
\hline 25. & Melihat mayat & Dihantui oleh mayat itu di dalam mimpi \\
\hline 26. & Main congklak saat malam hari & $\begin{array}{l}\text { Congklaknya bisa bermain sendiri saat } \\
\text { kita tidur }\end{array}$ \\
\hline 27. & $\begin{array}{l}\text { Menggunakan 2 piring yang } \\
\text { ditumpang saat makan }\end{array}$ & $\begin{array}{l}\text { Akan mempunyai suami/istri yang } \\
\text { banyak }\end{array}$ \\
\hline 28. & Tiduran setelah makan & Akan menjadi orang yang malas \\
\hline & & \\
\hline
\end{tabular}

Berdasarkan data hasil penelitian tersebut, ungkapan pamali yang berlaku dalam masyarakat identik dengan etika, nilai dan norma sosial. Tradisi pamali yang terdapat dalam masyarakat banjar cenderung lebih mengatur bagaimana seseorang harus menjaga perilaku. Kebanyakan dari remaja memang tidak mempercayai dampak dari pamali namun tetap mematuhi tradisi tersebut karena diyakini memiliki pesan tersirat tentang nilai dan norma dalam berperilaku.

Sedangkan akibat yang akan diterima jika melanggar pamali cenderung adalah hal yang menakutkan dan berupa kesialan, misalnya berkaitan dengan maut, kesehatan, rezeki, jodoh dan keluarga. Tidak dapat dipungkiri bahwa dampak pamali yang berkaitan dengan hal itulah yang masih mampu diterima oleh kebanyakan remaja. Dampak seperti itu juga yang cenderung lebih memberikan rasa takut dikalangan remaja.

Selain itu, ungkapan pamali juga berkaitan dengan alam gaib atau makhluk halus yaitu suatu hal yang banyak mengandung sifat ketayahulan. Ungkapan pamali seperti inilah yang cenderung ditakuti oleh kebanyakan remaja sehingga patuh terhadap pamali. Meskipun dampak pamali yang berkaitan dengan alam gaib atau makhluk halus tidak bisa dibuktikan secara ilmiah, sehingga menjadi keyakinan pribadi masing-masing dalam menanggapinya. Namun, ternyata mendapat tempat dan perhatian yang kuat dalam kepercayaan masyarakat banjar karena telah berlangsung secara turun-temurun.

Tradisi pamali selalu dituturkan secara turun-temurun dari ragam tujuan serta ragam budaya masyarakat yang mempengaruhinya. Oleh sebab itu, ungkapan pamali mengandung nilainilai tradisional maupun modern yang sangat tepat untuk dilestarikan keberadaannya meskipun ungkapan pamali mengandung ketakhayulan, namun justru di balik "kepamalian" yang ada dalam 
tuturan lisan masyarakat banjar memiliki sesuatu yang tersembunyi dari segi tujuan atau manfaat yang diadaptasi dengan nalar.

Sebagaimana telah diungkapkan sebelumnya bahwa remaja adalah masa transisi, dari periode anak-anak menuju periode dewasa. Dalam artian dewasa dalam hal fisik maupun pemikiran dan mental. Periode ini dianggap sebagai masa-masa yang sangat berperan penting dalam kehidupan seseorang, khususnya dalam pembentukan kepribadian.

Dengan kata lain, masa remaja dapat diartikan sebagai tahapan kehidupan dimana seseorang harus mempelajari banyak hal yang tidak dilakukan sebelumnya di masa anak-anak. Namun, harus dipelajari dan diterapkan agar bisa menjalani tahapan kehidupan di masa dewasa dengan baik. Masa remaja dikenal juga sebagai masa dimana seseorang ingin lebih banyak tahu dan mencoba banyak hal yang kemudian akan sangat menentukan pembentukan kepribadiannya.

Namun disisi lain, harapan sosial masyarakat yang menginginkan agar perilaku remaja mencerminkan nilai dan norma yang berlaku di masyarakat. Sehingga tradisi pamali yang memang telah dijalankan dan diyakini secara turun-temurun dalam masyarakat Banjar berperan sebagai salah satu alat kontrol sosial. Terutama dalam mengontrol perilaku anak-anaknya sesuai dengan tradisi yang berlaku dalam masyarakat.

Pamali seringkali menjadi momok yang menakutkan bagi remaja. Bahkan mampu menghadirkan kekhawatiran dan keresahan di kalangan remaja jika bersentuhan dengan hal-hal yang tidak berkenan tersebut. Dalam hal ini, hal yang ditakutkan oleh kebanyakan dari mereka adalah dampak dari pamali itu sendiri yang kemudian mengharuskan mereka untuk membatasi perilakunya dan tidak dapat bertindak bebas.

Remaja yang percaya terhadap pamali cenderung akan berhati-hati dalam bertindak, memiliki sikap sopan yang tinggi terhadap orang yang lebih tua dan sangat menghormati apa yang dikatakan oleh orangtua. Sebaliknya, remaja yang tidak percaya dengan pamali akan cenderung menunjukkan sikap yang berlawanan dengan remaja yang patuh terhadap pamali. Hal ini terjadi karena dampak dari pamali bukan sesuatu yang serta merta terjadi secara langsung, sehingga bagi sebagian orang masih diragukan kebenaran.

Keberlangsungan tradisi pamali sangat bergantung pada faktor lingkungan. Berdasarkan hasil wawancara dengan beberapa siswa/i di SMA Global Islamic Boarding School diperoleh informasi bahwa kebanyakan dari mereka mengenal tradisi pamali secara langsung melalui lisan oleh keluarga, terutama orangtua dan nenek atau kakek. Menariknya, tradisi pamali ini lebih banyak mengintervensi para remaja perempuan, karena berdasarkan data yang dikumpulkan ada beberapa pamali yang diperuntukan khusus bagi perempuan saja. Selain itu, fakta lain yang kami peroleh dari hasil wawancara adalah bahwa anak yang pendiam cenderung lebih mematuhi dan menghormati tradisi pamali dengan lebih baik.

Berbeda dengan remaja perempuan, beberapa remaja laki-laki justru menganggap bahwa tradisi pamali yang ditemui lingkungannya hanya sebatas tahayul karena hubungan sebab-akibat dalam tradisi pamali seringkali bersifat irasional. Oleh sebab itu, kebanyakan remaja laki-laki yang memiliki pergaulan yang luas tidak begitu percaya dengan tradisi pamali. Hal ini semakin diperkuat ketika mereka belum pernah mengalami dampak langsung dari tradisi pamali dalam kehidupannya.

Namun, tidak sedikit juga remaja laki-laki yang patuh dan percaya terhadap tradisi pamali yang kemudian membuat tindakannya menjadi lebih terbatas dan berhati-hati. Disisi lain, ada juga remaja yang tidak percaya terhadap dampak pamali tetapi tetap menjunjung tinggi tradisi tersebut dan mengambil pesan positif yang tersirat didalamnya.

Pada kenyataannya, pamali mampu mengintervensi remaja dengan menimbulkan rasa takut terhadap dampak yang ada pada tradisi pamali tersebut. Meskipun mereka yang takut terhadap pamali belum tentu memiliki kepercayaan yang tinggi terhadap pamali. Namun, remaja 
yang memiliki rasa percaya terhadap pamali cenderung akan takut terhadap dampak dari pamali tersebut.

Bahkan dari hasil tabulasi data yang kami himpun hanya satu remaja yang memiliki kepercayaan yang tinggi terhadap pamali namun tidak diikuti dengan rasa takut terhadap dampak yang ada dalam tradisi pamali. Hal ini dipengaruhi oleh beberapa faktor mulai dari lingkungan keluarga, teman bergaul, dan masyarakat sekitar, serta pengaruh arus globalisasi yang tak terbendung.

\subsection{Pengaruh Tradisi Pamali terhadap Kemampuan Berpikir Logis Remaja Dalam Masyarakat Banjar}

Penalaran merupakan suatu proses berpikir dalam menarik suatu kesimpulan yang berupa pengetahuan. Penalaran berfungsi sebagai daya dorong bagi setiap orang untuk berpikir namun tidak menggunakan perasaan. Penalaran pun memiliki ciri yaitu adanya pola berpikir yang sering disebut logika (Soekadijo, 1985: 7). Dalam pengertian lain penalaran bisa disebut sebagai kegiatan berpikir logis yang ditinjau dari suatu logika tertentu yang nantinya akan mendapatkan hasil berupa pengetahuan yang didapat melalui proses berpikir logis tanpa melupakan logika yang juga berperan didalamnya. Sehingga dalam hal ini berpikir logis mempunyai peranan yang vital terhadap pembentukan pola pikir khususnya bagi remaja.

Berpikir logis mempunyai peranan yang sangat penting dalam pembentukan perilaku remaja dalam kehidupan sehari-hari. Hal ini biasanya ditandai dengan perasaan atau kepercayaan mereka terhadap suatu hal yang mereka terima. Perbandingan yang cukup signifikan biasanya bisa ditemukan terhadap remaja yang memiliki kemampuan berpikir logis tinggi dan sebaliknya. Remaja yang memiliki kemampuan berpikir logis yang tinggi tidak serta merta langsung menerima atau mempercayai suatu hal yang sebelumnya belum pernah mereka temukan, namun akan berbeda jika kasus yang sama terjadi kepada remaja yang kemampuan berpikir logisnya rendah.

Menurut Suriasumantri (dalam Fadiana et al., 2017), karakteristik dari kemampuan berpikir logis adalah kemampuan menemukan suatu kebenaran berdasarkan aturan, pola atau logika tertentu. Oleh sebab itu, dalam proses penelitian ini dilakukan pendataan terhadap remaja SMA Global Islamic Boarding School berkaitan dengan pengaruh tingkat IQ, kemampuan berpikir logis dan kemampuan analisa berpikir dalam menanggapi tradisi pamali serta mengukur tingkat ketakutan dan keyakinan tentang tradisi pamali yang ada di lingkungan mereka, baik keluarga maupun masyarakat.

Pendataan ini kami uji untuk mendapatkan hasil apakah tingkat IQ seseorang, kemampuan berpikir logis dan kemampuan analisa berpikir dapat menentukan kecenderungan terhadap ketakutan dan kepercayaan pada tradisi pamali. Berikut data yang kami dapatkan dari pihak Bimbingan Konseling SMA Global Islamic Boarding School.

Tabel 2. Data Kemampuan Berpikir Logis Responden (Dokumentasi Guru BK)

\begin{tabular}{|c|c|c|c|}
\hline No. Urut Responden & IQ & Kemampuan Berpikir Logis & Kemampuan Analisa Berpikir \\
\hline 1 & 127 & H & M \\
\hline 2 & 124 & H & H \\
\hline 3 & 119 & M & H \\
\hline 4 & 127 & H & H \\
\hline 5 & 123 & H & H \\
\hline 6 & 105 & H & H \\
\hline 7 & 118 & H & M \\
\hline 8 & 118 & H & M \\
\hline 9 & 102 & H & M \\
\hline 10 & 121 & & \\
\hline
\end{tabular}




\begin{tabular}{|c|c|c|c|}
\hline No. Urut Responden & IQ & Kemampuan Berpikir Logis & Kemampuan Analisa Berpikir \\
\hline 11 & 112 & M & $\mathrm{M}$ \\
\hline 12 & 136 & $\mathrm{M}$ & $\mathrm{M}$ \\
\hline 13 & 137 & $\mathrm{M}$ & $\mathrm{M}$ \\
\hline 14 & 113 & $\mathrm{M}$ & $\mathrm{M}$ \\
\hline 15 & 131 & $\mathrm{M}$ & $\mathrm{M}$ \\
\hline 16 & 112 & $\mathrm{M}$ & M \\
\hline 17 & 122 & M & M \\
\hline 18 & 103 & $\mathrm{M}$ & $\mathrm{M}$ \\
\hline 19 & 101 & $\mathrm{H}$ & M \\
\hline 20 & 127 & $\mathrm{M}$ & $\mathrm{M}$ \\
\hline 21 & 132 & $\mathrm{M}$ & $\mathrm{M}$ \\
\hline 22 & 103 & $\mathrm{M}$ & M \\
\hline 23 & 119 & M & M \\
\hline 24 & 82 & $\mathrm{M}$ & $\mathrm{M}$ \\
\hline 25 & 87 & $\mathrm{M}$ & $\mathrm{M}$ \\
\hline 26 & 96 & $\mathrm{M}$ & $\mathrm{L}$ \\
\hline 27 & 85 & M & $\mathrm{M}$ \\
\hline 28 & 80 & $\mathrm{M}$ & M \\
\hline 29 & 97 & $\mathrm{M}$ & $\mathrm{M}$ \\
\hline 30 & 86 & $\mathrm{~L}$ & $\mathrm{M}$ \\
\hline 31 & 90 & $\mathrm{M}$ & $\mathrm{M}$ \\
\hline 32 & 94 & $\mathrm{M}$ & $\mathrm{M}$ \\
\hline 33 & 89 & $\mathrm{~L}$ & $\mathrm{M}$ \\
\hline 34 & 89 & $\mathrm{H}$ & $\mathrm{H}$ \\
\hline 35 & 83 & $\mathrm{M}$ & $\mathrm{L}$ \\
\hline 36 & 98 & $\mathrm{~L}$ & M \\
\hline 37 & 96 & M & M \\
\hline 38 & 92 & $\mathrm{M}$ & M \\
\hline
\end{tabular}

Keterangan :

$$
\begin{aligned}
\mathrm{H} & =\text { High/tinggi } \\
\mathrm{M} & =\text { Middle/sedang } \\
\mathrm{L} & =\text { Low/rendah }
\end{aligned}
$$

Data yang kami kumpulkan diatas menjadi bahan untuk mengukur pengaruh yang diberikan dengan adanya tradisi pamali terhadap perasaan takut dan keyakinan dalam menanggapi tradisi pamali. Selanjutnya kami melakukan pendataan berkaitan dengan hal diatas dengan memberikan responden kuesioner tentang pamali dan dampak yang dihasilkan. Berikut adalah hasil pengukuran yang telah kami lakukan:

Tabel 3. Data Hasil Tabulasi Kuesioner tentang Pandangan Responden terhadap Pamali

No. Urut Responden Perasaan Takut Keyakinan

\begin{tabular}{l|ll}
\hline 1 & 29 & 30 \\
2 & 53 & 49 \\
3 & 39 & 39 \\
4 & 30 & 40 \\
5 & 37 & 31 \\
6 & 34 & 37 \\
7 & 41 & 36 \\
8 & 39 & 40
\end{tabular}




\begin{tabular}{|c|c|c|}
\hline No. Urut Responden & Perasaan Takut & Keyakinan \\
\hline 9 & 29 & 32 \\
\hline 10 & 43 & 44 \\
\hline 11 & 28 & 28 \\
\hline 12 & 42 & 35 \\
\hline 13 & 43 & 34 \\
\hline 14 & 42 & 34 \\
\hline 15 & 38 & 33 \\
\hline 16 & 48 & 42 \\
\hline 17 & 46 & 51 \\
\hline 18 & 28 & 56 \\
\hline 19 & 43 & 32 \\
\hline 20 & 44 & 43 \\
\hline 21 & 34 & 35 \\
\hline 22 & 58 & 39 \\
\hline 23 & 31 & 29 \\
\hline 24 & 61 & 36 \\
\hline 25 & 52 & 52 \\
\hline 26 & 41 & 40 \\
\hline 27 & 51 & 50 \\
\hline 28 & 42 & 54 \\
\hline 29 & 37 & 45 \\
\hline 30 & 53 & 48 \\
\hline 31 & 41 & 31 \\
\hline 32 & 48 & 47 \\
\hline 33 & 49 & 38 \\
\hline 34 & 40 & 39 \\
\hline 35 & 59 & 28 \\
\hline 36 & 47 & 39 \\
\hline 37 & 67 & 59 \\
\hline 38 & 48 & 44 \\
\hline
\end{tabular}

Keterangan:
Kurang takut/Kurang Percaya
Takut/Percaya
Sangat Takut/Sangat Percaya

Berdasarkan hasil diatas kami menarik kesimpulan bahwa mereka yang percaya terhadap tradisi pamali cenderung akan takut terhadap dampak yang dihasilkan dari pamali tersebut. Dalam proses pengukuran terhadap rasa takut dan kepercayaan mereka kami mengakumulasikan poin yaitu: 1) tidak takut/tidak percaya, 2) takut/percaya, 3) sangat takut/sangat percaya. Hanya ada 2 dari 38 remaja yang tidak percaya namun tetap memiliki rasa yang takut terhadap tradisi pamali. Namun, keadaan sebaliknya justru berbeda yaitu mereka yang takut terhadap dampak dari tradisi pamali belum tentu bisa mempercayai hal tersebut.

Kemudian untuk remaja yang memiliki kemampuan berpikir logis yang tinggi cenderung akan kurang mempercayai serta kurang takut terhadap dampaknya. Sedangkan remaja dengan kemampuan berpikir logis yang rendah cenderung akan takut disertai adanya perasaan percaya terhadap tradisi pamali. Namun, mayoritas responden memang memiliki rasa takut namun tidak disertai perasaan percaya terhadap dampak yang ada dalam tradisi pamali tersebut. Hal ini sesuai 
dengan pendapat Sudarminta (2002: 40) bahwa tanpa logika, penalaran tidak mungkin dilakukan, dan tanpa penalaran tidak akan ada pengetahuan yang benar.

Pamali secara sederhana dapat diartikan sebagai pantangan atau larangan yang apabila dilanggar akan mendapat kesialan atau dampak buruk bagi yang melanggarnya. Dalam hal ini, masyarakat Banjar memiliki keyakinan bahwa tradisi pamali mengandung nilai-nilai tradisional maupun modern yang dianggap tepat untuk dilestarikan sebagai budaya. Meskipun terkadang tradisi pamali diidentikan dengan tahayul.

Namun, hal ini tidak lantas menjadikan kepercayaan sebagian masyarakat menjadi surut. Pamali diakui memiliki peranan dan pengaruh yang penting dalam proses pembentukan perilaku remaja menuju proses pendewasaan. Dalam hal ini, pamali dianggap mampu menjadi batasan dan acuan bagi para orangtua untuk mendidik anaknya sesuai dengan apa yang mereka dan masyarakat harapkan.

Sebagaimana diungkapkan sebelumnya bahwa tradisi pamali sangat berpengaruh bagi kehidupan remaja terutama bagi yang patuh dan meyakini kebenaran dampak dari pamali tersebut. Bahkan berdasarkan hasil wawancara, remaja yang meragukan kebenaran pamali pun merasakan kekhawatiran akan dampak pamali jika melanggarnya.

Makna yang terkandung dalam pamali sebenarnya menyiratkan pesan positif dalam mengarahkan seseorang untuk berperilaku baik yang sesuai dengan nilai dan norma yang ada di masyarakat. Oleh sebab itu, selain berpengaruh terhadap perilaku remaja, pamali juga berperan untuk membentuk kesadaran diri untuk selalu berperilaku baik dan sopan.

Di kalangan remaja kekinian, pengaruh pamali mengalami kemerosotan terlebih terhadap remaja yang tidak begitu peduli dan percaya pada ancaman dan dampak apabila melanggar tradisi pamali hingga mereka merasakan dan mengalami sendiri dampaknya. Meskipun demikian, tidak diragukan lagi bahwa tradisi pamali masih menunjukkan eksistensinya hingga saat ini.

Remaja adalah periode penting untuk mempersiapkan diri ke tahap kehidupan selanjutnya. Pada masa inilah remaja dituntut untuk membentuk pribadi yang lebih baik karena apa yang dilakukan sekarang akan mempengaruhi hasil yang nantinya didapatkan pada kehidupan selanjutnya. Mematuhi tradisi pamali secara tidak langsung dapat membimbing kehidupan remaja ke arah yang lebih teratur.

Tidak dapat dipungkiri bahwa terjadi kemerosotan tradisi pamali dikalangan remaja yang ditunjukan dengan sikap abai terhadap pamali yang sebenarnya sudah menjadi bagian dalam pembentukan nilai dan norma dalam masyarakat. sebagaimana hasil tabulasi data dari kuesioner/angket bahwa kebanyakan remaja mulai mengalami penurunan kepercayaan terhadap tradisi pamali. Pesatnya arus globalisasi, wawasan yang luas, pola pikir yang terbuka, kemampuan membedakan suatu hal yang jelas ataupun tidak, menjadikan tradisi pamali yang merupakan bagian penting dalam kehidupan masyarakat banjar secara bertahap penggunaannya mulai memudar.

\section{KESIMPULAN DAN SARAN}

Intervensi tradisi pamali terhadap kehidupan remaja ditunjukan dengan adanya rasa percaya dan takut terhadap pamali baik pada remaja yang memiliki kemampuan berpikir logis rendah (IQ 80100) maupun yang memiliki kemampuan berpikir logis tinggi (IQ 101-140). Remaja IQ 80-100 lebih mudah terpengaruh dengan pamali bila dibandingkan dengan remaja IQ 101-140, artinya remaja IQ 101-140 lebih mampu menyaring dampak dari pamali.

\section{DAFTAR PUSTAKA}

Danandjaja, J. (1984). Folklore Indonesia. Jakarta: Grafiti.

Fadiana, M., Amin, S. M., \& Lukito, A. (2017). Pemetaan Kemampuan Berpikir Logis Siswa SMP Kelas VII. Prosiding SNasPPM, 2(1), 279-284. 
Geldard, K. (2012). Konseling Remaja. Yogyakarta: Pustaka Pelajar.

Harpriyanti, H., \& Komalasari, I. (2018). Makna dan Nilai Pendidikan Pamali Dalam Masyarakat Banjar di Desa Barikin Kabupaten Hulu Sungai Tengah. STILISTIKA: Jurnal Bahasa, Sastra, Dan Pengajarannya, 3(2), 242-252.

Jamalie, Z., \& Juhriyansyah, D. (2013). Pamali sebagai Nilai Tradisional Pencitraan Publik Figur Masyarakat Banjar. Institut Agama Islam Negeri Antasari.

Jamiah, H., Assya'bani, R., \& Zubaidillah, H. (2021). Analisis Konstruksi Sosial Dalam Pemaknaan Tradisi Lisan Budaya Pamali Masyarakat Banjar. ISoLEC Proceedings, 5(1), 288-292.

Khodijah, N. (2006). Psikologi Belajar. Palembang: IAIN Raden Fatah Press.

Rahmat, P. S. (2009). Penelitian Kualitatif. EQUILBRIUM, 5(9), 1-8.

Soekadijo, R. G. (1985). Logika Dasar, Tradisional, Simbolik, dan Induktif. Jakarta: Gramedia.

Sudarminta, J. (2002). Epistemologi Dasar: Pengantar Filsafat Pengetahuan. Yogyakarta:

Kanisius.

Sugara, H., \& Perdana, T. I. (2021). Nilai Moral dan Sosial Tradisi Pamali di Kampung Adat Kuta

Sebagai Pendidikan Karakter. Edukasi: Jurnal Pendidikan, 19(1), 1-15.

Sugiyono. (2016). Memahami Penelitian Kualitatif. Bandung: Alfabeta. 